\section{Growth, Muscle Proximate Composition and Whole-Body Nutrient Status of Labeo rohita Fed Acidified and Phytase Pre-Treated Sunflower Meal Based Diet}

\author{
Muhammad Afzal', Mahroze Fatima ${ }^{2}$, Aasma Qamar ${ }^{1}$, Muhammad Farhan ${ }^{1}$ and \\ Syed Zakir Hussain Shah ${ }^{3, *}$ \\ ${ }^{1}$ Fish Nutrition Laboratory, Department of Zoology, Wildlife and Fisheries, University \\ of Agriculture, Faisalabad \\ ${ }^{2}$ Department of Fisheries and Aquaculture, University of Veterinary and Animal \\ Sciences, Lahore \\ ${ }^{3}$ Department of Zoology, University of Gujrat, Gujrat
}

\begin{abstract}
A B S T R A C T
Present study was conducted to evaluate the effect of citric acid (CA) and phytase (PHY) pre-treatment on growth, muscles proximate composition, whole body proximate composition and minerals status of Labeo rohita juveniles. Four experimental diets were prepared by supplementing citric acid ( 0 and $2 \%$ ) and phytase $(0$ and $1000 \mathrm{FTU} / \mathrm{kg})$ in $2 \times 2$ factorial arrangements. Total 180 juveniles $(3.45 \pm 0.013)$ were distributed to 12 tanks having triplicate tank for each test diet. Weight gain of each replicate was recorded on weekly basis. Results showed that growth of $L$. rohita juveniles was significantly improved by the supplementation of CA and PHY. Improved $(p<0.05)$ dry mater, crude protein, crude fat, and crude ash contents in the muscles and whole body of juveniles in response to CA and PHY supplementations were observed. Again, dietary acidification with CA also improved $(p<0.05)$ the whole-body mineralization. Moreover, PHY pretreatment also resulted in higher $(p<0.05)$ mineral deposition in the body as compared to control group. Both supplements interacted positively $(p<0.05)$ to enhance most of body minerals. In short, CA as well as PHY efficiently enhanced growth performance, muscle proximate composition and whole-body nutrient status of $L$. rohita when fed on sunflower meal-based diet.
\end{abstract}
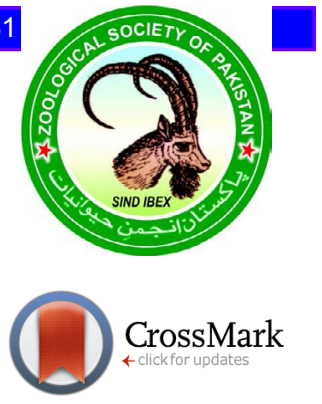

\section{INTRODUCTION}

$\mathrm{T}$ he development of aquaculture industry mainly depends upon the formulation of balanced feed (Shaheen et al., 2000) because it costs about $45-50 \%$ of production expenditures (Craig and Helfrish, 2002). Fishmeal is considered as vital ingredient during feed formulation to provide fundamental nutrients including essential fatty acids, amino acids, vitamins and major as well as trace minerals (Zhou et al., 2004). However, due to high price, increased requirement and unstable supply of fishmeal, it is compulsory to search for other alternative protein sources (Pham et al., 2008). Agricultural byproducts like sunflower meal are considered most proficient sources of energy and protein (Hardy, 2000). The feed formulations having plant protein sources are assumed to be environmental friendly due to less $\mathrm{P}$ contents and economical aqua feeds (Cheng and Hardy, 2002).

\footnotetext{
Corresponding author: zakiruaf@gmail.com 0030-9923/2020/0003-0937 \$ 9.00/0

Copyright 2020 Zoological Society of Pakistan
}

Sunflower meal (SFM) is nutritionally important feed ingredient containing up to $40 \%$ protein contents which depends on the dehulling techniques and oil mining methods (Mushtaq et al., 2006). Its global production has been increased for the past few years which renders the need of a highly suitable alternate plant based protein source in fish diet for future accessibility. The one major problem related to use of plant protein is the occurrence of anti-nutritional factors. Anti-nutrients have been defined as substances which by themselves, or through their metabolic products arising in living systems, reduce feed utilization, imbalance the amino acid profile and affect the health and production of animals (Makkar, 1993).

Phytic acid or phytate (myo-inositol-1, 2, 3, 4, 5, 6-hexakisphosphates) is the most common anti nutrient present in plant seeds (Francis et al., 2001) that contains about two-third of the total $\mathrm{P}$ in plants. However, fish is unable to utilize phytate-P (Usmani and Jafri, 2002) and this unused phytate bound $\mathrm{P}$ is excreted out and can contribute to the eutrophication of water body. Phytate forms the insoluble chelated complexes with essential minerals such as $\mathrm{Zn}, \mathrm{K}, \mathrm{Mn}, \mathrm{Ca}, \mathrm{Cu}, \mathrm{Na}, \mathrm{Fe}$ and $\mathrm{Mg}$ 
(Knuckles et al., 1989). It also complexes with proteins and vitamins and reduces their absorption and utilization. Furthermore, it interferes with lipid and starch digestibility (Cosgrove, 1966). There are several ways to release these bound nutrients from phytate including, heat treatment, fermentation but more important are chelation with an organic acid and enzyme treatment. Agastric fishes lack the acid secretions as well as enzyme to hydrolyze phytate to release the bound nutrients (Storebakken et al., 2000).

Organic acids are used in feed to physically degrade phytate complex and to release chelated nutrients including bound P (Zyla et al., 1995). It has been reported that organic acids are efficiently used in aquaculture to improve the disease resistance, growth performance and nutrients utilization (Ng and Koh, 2011; Koh et al., 2014) due to this phytate hydrolyzing capability. Citric acid (CA) may also work as chelating agents that bind with various cations in the intestine and make them easy to be absorbed (Ravindran and Kornegay, 1993). It was observed that CA addition in fish diet improved utilization of $\mathrm{P}$ and other minerals (Sugiura et al., 2001).

Use of hydrolase enzymes is another technique widely used in fish nutrition to degrade phytate. Microbial phytase (PHY) is a hydrolase enzyme capable of hydrolysis of phytate results in the release of bound nutrients. It also have the potential to increase the absorption of minerals (Cheng and Hardy, 2003; Yoo et al., 2005). Studies have shown the effectiveness of PHY in improving P availability from phytate leading to enhanced growth of several species including carps (Schafer et al., 1995; Sardar et al., 2007; Baruah et al., 2007a; Phromkunthong et al., 2010). Phytase supplementation also resulted in increased body protein level in Oreochromis niloticus, fed plant meal based diet (Olusola and Nwanna, 2014). Improved P and other mineral contents in the body in response to PHY supplementation was reported in Atlantic salmon (Carter and Sajjadi, 2011), bible carp Carassius auratus gibelio (Liu et al., 2011), rainbow trout (Dalsgaard et al., 2009) and olive flounder (Pham et al., 2008).

Like all other enzymes PHY work efficiently under specific conditions, most importantly at $\mathrm{pH}$ ranges of 5.05.5 and 2.5. Citric acid not only solubilize phytate but also provides optimum $\mathrm{pH}$ for PHY action (Ravindran and Kornegay, 1993). An interaction between PHY and CA was reported for bone ash and mineral contents in Labeo rohita juveniles (Baruah et al., 2005). The addition of 5\% CA and PHY in the diet of rainbow trout, Oncorhynchus mykiss also significantly increased the apparent absorption of $\mathrm{Mg}$ and P (Sugiura et al., 2001). Significant interaction between CA and PHY has been found on the specific growth rate, protein efficiency ratio and weight gain in $L$. rohita (Baruah et al., 2007a). The nutritional value of diet was increased when it is supplemented with CA and PHY (Forster et al., 1999). Both the supplements also enhanced the uptake and utilization of nutrients and $\mathrm{Na}, \mathrm{Mn}, \mathrm{K}, \mathrm{P}$, $\mathrm{Cu}, \mathrm{Mg}$ and $\mathrm{Zn}$ in rainbow trout (Oncorhynchus mykiss) (Cheng and Hardy, 2003) and Korean rockfish Sebastes schlegeli (Yoo et al., 2005). Phytase and CA collectively showed the potential to reduce phosphorus discharge in Atlantic salmon, Salmo salar (Sajjadi and Carter, 2004), rainbow trout Oncorhynchus mykiss (Vielma et al., 2002) and Cyprinus carpio (Phromkunthong et al., 2010).

Previous work conducted in our laboratory (Akram et al., 2016; Shah et al., 2015a, b, c, 2016; Afzal et al., 2019) reports the dietary benefits of CA and PHY posttreatment (top spraying after pellet formation). The present experiment was planned to study the effect of CA and PHY pre-treatment on growth, muscle proximate composition and body nutrient profile of $L$. rohita when fed sunflower meal-based diet.

\section{MATERIALS AND METHODS}

The present experiment was conducted in Fish Nutrition Laboratory, Department of Zoology, Wildlife and Fisheries, University of Agriculture, Faisalabad, Pakistan.

\section{Experimental diets and design}

A 60 days $2 \times 2$ factorial experiment was conducted under completely randomized design to examine the effects of CA and PHY pre-treatment on growth, muscles proximate composition and whole body status of $L$. rohita juveniles. Four SFM based experimental diets were formulated. All diets were supplemented with CA (\%) and PHY (FTU/kg) at the level of 0,$0 ; 2,0 ; 0,1000$ and 2,1000, respectively. SFM1 was incubated without supplementation of CA and PHY, SFM2 was incubated with $2 \%$ CA supplementation, SFM3 was incubated with the supplementation of $1000 \mathrm{FTU} / \mathrm{kg}$ PHY, while, SFM4 was incubated with both supplements i.e. $2 \%$ CA and $1000 \mathrm{FTU} / \mathrm{kg}$ PHY. The process of pre-treatment of the diets was as follows: $1 \mathrm{~kg}$ of the finely ground $(0.05$ $\mathrm{mm}$ ) ingredients, CA and PHY were mixed with $1.5 \mathrm{~L}$ of distilled water to form paste. The paste was first incubated at $40^{\circ} \mathrm{C}$ for $15.5 \mathrm{~h}$ and later oven dried at $60^{\circ} \mathrm{C}$ for 12.5 $\mathrm{h}$. This dried paste of ingredients was again blended into powdery form (Nwanna et al., 2008). Again, dough for pelleting was made by adding distilled water $(15 \%)$ and pellets of $2 \mathrm{~mm}$ were prepared by hand pelletizer, blow dried and stored at $-20^{\circ} \mathrm{C}$ throughout the experimental trial. Phytase solution was prepared by dissolving $2 \mathrm{~g}$ of powder microbial PHY in $1000 \mathrm{ml}$ of distilled water (Robinson et al., 2002). One FTU is the phytase activity unit that liberates $1 \mu \mathrm{mol}$ of inorganic orthophosphate/min from $5.1 \mathrm{mmol} / \mathrm{L}$ substrate (sodium phosphate) at $5.5 \mathrm{pH}$ 
and $37^{\circ} \mathrm{C}$ temperature (Engelen et al., 1994). Composition of experimental diets is mentioned in Table I.

Table I.- Ingredient and proximate composition (\%) of sunflower meal based diet.

\begin{tabular}{lcccc}
\hline Ingredients & SFM1 & SFM2 & SFM3 & SFM4 \\
\hline SFM & 65 & 65 & 65 & 65 \\
Wheat flour & 14 & 12 & 13.95 & 11.95 \\
Rice polish & 10 & 10 & 10 & 10 \\
Fish meal & 5 & 5 & 5 & 5 \\
Soybean oil & 3 & 3 & 3 & 3 \\
Vitamin premix ${ }^{1}$ & 1 & 1 & 1 & 1 \\
Mineral mixture $^{2}$ & 1 & 1 & 1 & 1 \\
Ascorbic acid & 1 & 1 & 1 & 1 \\
Citric acid & 0 & 2 & 0 & 2 \\
Phytase & 0 & 0 & 0.05 & 0.05 \\
Phytase (FTU/kg) & 0 & 0 & 1000 & 1000 \\
Total & 100 & 100 & 100 & 100
\end{tabular}

Proximate composition

$\begin{array}{lllll}\text { Dry matter } \quad 97.59 \pm 0.04 & 97.51 \pm 0.05 & 97.94 \pm 0.20 & 97.67 \pm 0.10\end{array}$

$\begin{array}{lllll}\text { Crude protein } \quad 33.93 \pm 0.73 & 34.62 \pm 0.84 & 34.06 \pm 0.52 & 34.44 \pm 1.0\end{array}$

$\begin{array}{lllll}\text { Crude fat } & 10.81 \pm 0.41 & 11.17 \pm 0.06 & 11.11 \pm 0.25 & 11.26 \pm 0.33\end{array}$

${ }^{1}$ Each $\mathrm{kg}$ of vitamin premix contains Vitamin A (15 MIU) Vitamin $\mathrm{D}_{3}$ (3 MIU) Vitamin E (6000 IU), Vitamin K (4000 mg), Vitamin $B_{1}(5000$ $\mathrm{mg})$, Vitamin $\mathrm{B}_{2}(6000 \mathrm{mg})$ Vitamin B6 $(4000 \mathrm{mg}), \mathrm{B}_{9}(750 \mathrm{mg})$, Vitamin $\mathrm{B}_{12}$ (9000 ug), Calcium pantothenate (10000mg), Vitamin C (15000mg), Nicotinic acid $(25000 \mathrm{mg}) .{ }^{2}$ Each $\mathrm{kg}$ of mineral mixture contains; Ca (Calcium) $155 \mathrm{gm}, \mathrm{P}$ (Phosphorous) 135gm, Mg (Magnesium) 55gm, $\mathrm{Na}$ (Sodium) 45gm, Zn (Zinc) $3000 \mathrm{mg}$, Mn (Manganese) $2000 \mathrm{mg}, \mathrm{Fe}$ (Iron) $1000 \mathrm{mg}, \mathrm{Cu}$ (Copper) $600 \mathrm{mg}$, Co (Cobalt) $40 \mathrm{mg}$, I (Iodine) $40 \mathrm{mg}$, Se (Selenium) 3mg. ${ }^{3}$ The $0.05 \mathrm{~g}$ of PHY provides $1000 \mathrm{FTU}$, where, the FTU is one phytase activity unit that liberates $1 \mu \mathrm{mol}$ of inorganic orthophosphate $/ \mathrm{min}$ from $5.1 \mathrm{mmol} / \mathrm{L}$ substrate (sodium phosphate) at 5.5 $\mathrm{pH}$ and $37 \circ \mathrm{C}$ temperature (Engelen et al., 1994).

\section{Experimental conditions and fish feeding}

Labeo rohita juveniles were obtained from Government Fish Seed Hatchery, Faisalabad. The juveniles were stocked in V-shaped tanks with proper aeration to acclimatize to the laboratory conditions. During acclamation period the fish were fed once daily on basal diet (Allan and Rowland, 1992). Before beginning of experiment, L. rohita juveniles were given the prophylactic dip in $\mathrm{NaCl}$ solution $(5 \mathrm{~g} / \mathrm{L})$ to avoid the fungal infection and to remove the ectoparasites (Rowland and Ingram, 1991). A group of 15 fish (initial weight, $3.45 \pm 0.013$ ) were randomly stocked in each experimental tank and fed twice a day, 6 days a week. Triplicates tanks were allotted to each experimental treatment. Fish were initially fed a ration equal to $2 \%$ of their live wet weight which was adjusted according to apparent satiation of fish throughout the feeding trail. Fish were fed for three $\mathrm{h}$ and then remaining diet was recollected to determine feed conversion ratio (FCR). After that, fish were moved to clean water tanks, experimental tanks were washed and refilled with filtered fresh water. Aeration was provided to all the tanks round-the clock through capillary system. Important water quality variables were monitored constant i.e. dissolved oxygen in the range of $5.8-7.3 \mathrm{mg} / \mathrm{L}$ by using D.O. meter (Jenway, Model 970), $\mathrm{pH}$ in range of 7.4-8.6 and temperature in the limit of $24.9-28.7^{\circ} \mathrm{C}$ by using $\mathrm{pH}$ meter (Jenway, Model 3510).

\section{Sample collection and chemical analysis}

Fish of each experimental tank were bulk weighed at the initiation of feeding trial and weight gain was recorded weekly to determine growth performance. The chemical analyses of feed, muscles and whole body fish were performed according to the standard methods (AOAC, 2000). At the end of feeding trial fish were starved for 24 h,10 fish from each tank were collected, anesthetized by immersing in $3000 \mathrm{mg} / \mathrm{L}$ clove oil solution for 40-60s and sacrificed by sharp blow on head. Five fish were minced as such and used for whole body analysis while muscles of other 5 fish were separated and analyzed for muscle proximate composition. The proximate composition of diet, muscles and whole body was determined as follows: dry matter contents by oven drying at $105^{\circ} \mathrm{C}$ for $12 \mathrm{~h}$; crude protein $\left(\mathrm{N}_{2} \times 6.25\right)$ was estimated by micro Kjeldahl method; crude fat contents were determined by petroleum ether extraction method through Soxtec HT2 1045 system; crude ash was measured by igniting the sample at $650^{\circ} \mathrm{C}$ for $12 \mathrm{~h}$ in electric furnace (Eyela-TMF 3100) to a constant weight. For mineral estimation the samples of whole body were digested in a boiling nitric acid and percholoric acid mixture (3:1). After appropriate dilution, $\mathrm{Ca}, \mathrm{Mg}, \mathrm{Cu}, \mathrm{Fe}, \mathrm{Mn}$ and $\mathrm{Zn}$ were measured by atomic absorption spectrophotometer (Hitachi Polarized Zeeman AAS, Z-8200, Japan). The P was analyzed colorimetrically by UV/VIS spectrophotometer (Shimadzu, UV 265 FW, Kyoto, Japan) at $750 \mathrm{~nm}$ wavelength. The $\mathrm{Na}$ and $\mathrm{K}$ were analyzed by using flamephotometer (Jenway PFP-7, UK).

\section{Statistical analysis}

The main and interaction effects of CA and PHY were calculated by applying two way analysis of variance on obtained data. The results were considered significant at $p<0.05$ (Snedecor and Cochran, 1991). As only two levels of each additive ( 0 and $2 \%$ for CA and 0 and 1000 FTUkg $^{-1}$ for $\mathrm{PHY}$ ) were used, the significant or non-significant response of these factors and their interaction for observed 
responses can be clearly confirmed by the $p$-value of two way analysis of variance. Therefore, no post hoc test was applied. CoStat computer package (Version 6.303, PMB 320, Monterey, CA, 93940 USA) was used for statistical analyses.

\section{RESULTS}

The growth performance of L. rohita as a result of dietary CA and PHY supplementation is shown in Table II. Citric acid addition in feed improved weight gain percent (WG\%), specific growth rate (SGR), and feed conversion ratio (FCR) by $37.91 \%, 19.85 \%$, and $9.091 \%$, respectively. Similarly, supplementation of $1000 \mathrm{FTU} / \mathrm{kg}$ phytase also increased $\mathrm{WG} \%$, SGR, and FCR by, 38.23, 19.85, and $10.20 \%$ when compared to control diet. Citric acid and PHY interacted positively and resulted in increased $(p<0.05)$ SGR by $19.85 \%$, FCR was decreased by $9.09 \%$ as compare to control diet, while non-significant interaction among additives was observed for $\mathrm{WG} \%$.

Muscle proximate composition of L. rohita was significantly $(p<0.05)$ improved by supplementation of $\mathrm{CA}$ in feed (Table III). Citric acid improved dry matter, crude protein, crude fat and crude ash contents of muscles upto $4.20,9.14,11.47$ and $23.82 \%$, respectively. Similar improvement in dry matter, crude protein, crude fat and crude ash upto $5.99 \%, 11.78 \%, 15.36 \%$ and $23.82 \%$ were observed as a result of phytase pre-treatment of feed. Although both supplements showed the positive interaction potential to further improve the nutrient profile of muscles but this interaction effect remained non-significant.

Effects of PHY, CA and their combination on whole body proximate composition are summarized in Table IV. Fish group fed CA supplemented diet showed significantly $(p<0.05)$ improved percentage of whole body dry matter, crude protein, crude fat and crude ash contents by $7.10 \%$,

Table II.- Growth performance of $L$. rohita fed citric acid and phytase pre-treated sunflower meal based diets.

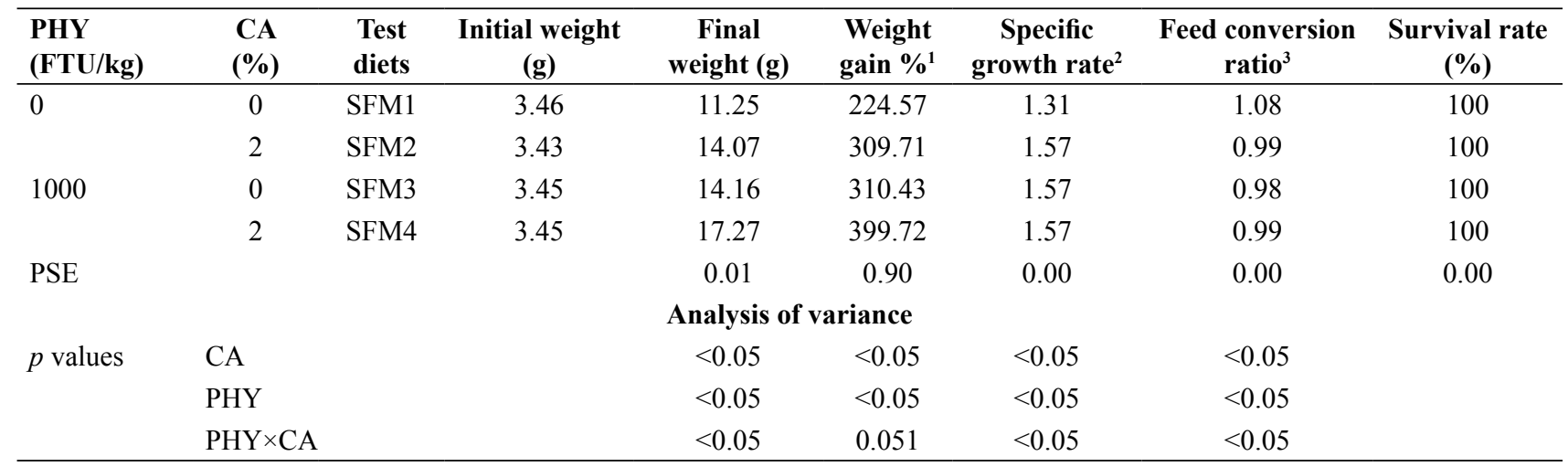

The data are means of two replicates; PSE, pooled; $\mathrm{SE}=\sqrt{\mathrm{MSE}} / \mathrm{n}$ (where MSE $=$ mean-squared error). ${ }^{1}$ Weight gain $(\%)=($ Final weight - Initial weight) $/$ Initial weight $\times 100 .{ }^{2} \mathrm{SGR}=\ln ($ Final weight - Initial weight $) /$ day $\times 100 .{ }^{3} \mathrm{FCR}=$ Total dry feed intake $(\mathrm{g}) /$ Wet weight gain $(\mathrm{g})$.

Table III.- Muscle proximate composition of $L$. rohita fed citric acid and phytase pre-treated sunflower meal based diets.

\begin{tabular}{|c|c|c|c|c|c|c|}
\hline PHY (FTU/kg) & CA $(\%)$ & Test diets & Dry matter (g/kg) & Crude protein (g/kg) & Crude fat (g/kg) & Crude ash (g/kg) \\
\hline \multirow[t]{2}{*}{0} & 0 & SFM1 & 254.25 & 127.55 & 55.92 & 3.56 \\
\hline & 2 & SFM2 & 262.82 & 136.37 & 48.87 & 4.05 \\
\hline \multirow[t]{2}{*}{1000} & 0 & SFM3 & 265.21 & 138.54 & 48.42 & 4.11 \\
\hline & 2 & SFM4 & 274.18 & 147.3 & 40.67 & 4.63 \\
\hline PSE & & & 0.84 & 0.70 & 0.43 & 0.01 \\
\hline \multicolumn{7}{|c|}{ Analysis of variance } \\
\hline \multirow[t]{3}{*}{$p$ values } & PHY & & $<0.05$ & $<0.05$ & $<0.05$ & $<0.05$ \\
\hline & $\mathrm{CA}$ & & $<0.05$ & $<0.05$ & $<0.05$ & $<0.05$ \\
\hline & $\mathrm{PHY} \times \mathrm{CA}$ & & 0.82 & 0.10 & 0.44 & 0.10 \\
\hline
\end{tabular}

The data are means of two replicates; PSE, pooled; SE, $\sqrt{ } \mathrm{MSE} / \mathrm{n}$ (where MSE= mean-squared error). 
$6.83 \%, 12.02 \%$ and $11.16 \%$, respectively as compared to control group. Similarly, addition of 1000 FTU/kg PHY significantly $(p<0.05)$ enhanced the concentration of dry matter, crude protein, crude fat and crude ash by $8.41 \%$, $8.51 \%, 14.88 \%$ and $12.69 \%$, respectively in comparison of fish fed without PHY supplemented diet. A significant $(p<0.05)$ interaction was observed between CA and PHY for dry matter, crude fat and crude ash which had resulted in $13.89 \%, 27.20 \%$ and $22.08 \%$ increased nutrient contents in the fish body, respectively in comparison of their independent effects. The crude protein of whole body was not significantly affected by interaction of both supplements.

Effects of CA and PHY pre-treatment on whole body mineral status are presented in Table V. Dietary acidification with CA had resulted in improved $(p<0.05)$ whole body $\mathrm{Ca}, \mathrm{Mg}, \mathrm{Cu}, \mathrm{Zn}, \mathrm{Mn}, \mathrm{Fe}, \mathrm{P}, \mathrm{Na}$ and $\mathrm{K}$ by $10.29 \%, 25.64 \%$, $14.97 \%, 8.73 \%, 16.07 \%, 8.45 \%, 21.63 \%, 12.76 \%$ and $14.66 \%$, respectively. Also, supplementation of phytase (1000 FTU/kg) significantly improved the concentration of $\mathrm{Ca}, \mathrm{Mg}, \mathrm{Cu}, \mathrm{Zn}, \mathrm{Mn}, \mathrm{Fe}, \mathrm{P}, \mathrm{Na}$ and $\mathrm{K}$ in whole body of fingerlings by $12.01 \%, 29.75 \%, 15.39 \%, 9.479 \%, 17.80 \%$, $8.69 \%, 22.67 \%, 12.76 \%$ and $15.45 \%$, respectively. However, Interaction of both the supplements caused further deposition $(p<0.05)$ of $\mathrm{Ca}(4.39 \%), \mathrm{Cu}(31.14 \%)$, Fe $(29.31 \%), \mathrm{P}(46.01 \%), \mathrm{Na}(27.34 \%)$ and $\mathrm{K}(23.37 \%)$, while no significant interaction effect was observed for $\mathrm{Mg}, \mathrm{Zn}$ and $\mathrm{Mn}$.

Table IV.- Whole body proximate composition of $L$. rohita fed citric acid and phytase pre-treated sunflower meal based diets.

\begin{tabular}{lcccccc}
\hline PHY (FTU/kg) & CA (\%) & Test diets & Dry matter $(\mathbf{g} / \mathbf{k g})$ & Crude protein $(\mathbf{g} / \mathbf{k g})$ & Crude fat $(\mathbf{g} / \mathbf{k g})$ & Crude $\mathbf{~ a s h ~}(\mathbf{g} / \mathbf{k g})$ \\
\hline 0 & 0 & SFM1 & 251.90 & 126.92 & 47.89 & 3.94 \\
\multirow{2}{*}{1000} & 2 & SFM2 & 254.99 & 128.91 & 42.75 & 4.38 \\
& 0 & SFM3 & 254.99 & 128.91 & 41.68 & 4.44 \\
\multirow{2}{*}{ PSE } & 2 & SFM4 & 267.86 & 136.55 & 37.65 & 4.81 \\
& & & 0.42 & 0.38 & 0.67 & 0.01 \\
$p$ values & & & Analysis of variance & $<0.05$ & $<0.05$ \\
& PHY & & $<0.05$ & $<0.05$ & $<0.05$ & $<0.05$ \\
& CA & & $<0.05$ & $<0.05$ & $<0.05$ & $<0.05$ \\
\hline
\end{tabular}

The data are means of two replicates; $\mathrm{PSE}=$ pooled $\mathrm{SE}=\sqrt{\mathrm{MSE}} / \mathrm{n}$ (where $\mathrm{MSE}=$ mean-squared error).

Table V.- Whole body mineral composition of $L$. rohita fed citric acid and phytase pre-treated sunflower meal based diets.

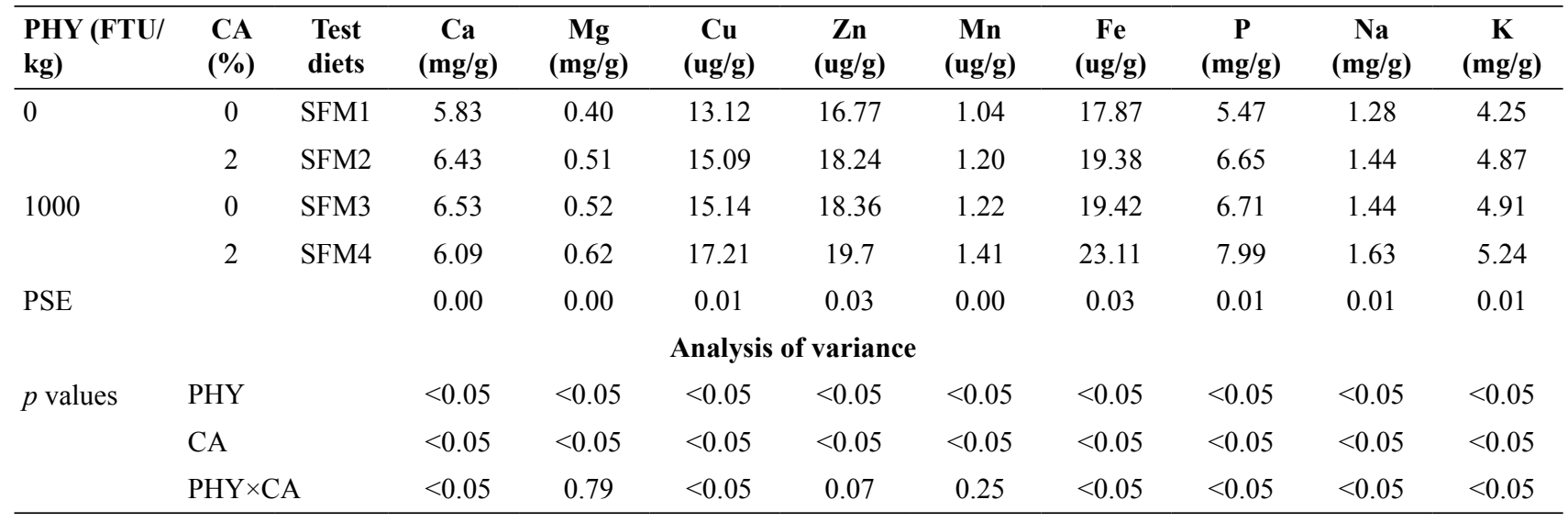

The data are means of two replicates; PSE $=$ pooled $\mathrm{SE}=\sqrt{\mathrm{MSE}} / \mathrm{n}$ (where $\mathrm{MSE}=$ mean-squared error). 


\section{DISCUSSION}

Citric acid supplementation in SFM based diet improved growth and feed performance in the present study. This growth improvement may owe to more $\mathrm{P}$ availability and utilization by $L$. rohita, which was liberated as a result of phytateP solubility at lowered gut $\mathrm{pH}$ provided by CA present in the diet (Cross et al., 1990). Phytate breakdown also results in release of other bound nutrients and minerals as well which are responsible for increase in growth rate. Growth improvement is also perhaps due to the physiological fact that during high intake of protein rich feed or during early age of animal, the hydrochloric acid level in stomach becomes insufficient for proper activation of pepsin and other pancreatic enzymes. This problem is resolved by addition of acidifiers in diet (Eidelsburger, 1997). Increased growth performance was also recorded for red sea bream (Sarker et al., 2007) and rainbow trout (Pandey and Satoh, 2008), which is in close agreement with our results.

Growth performance, in the present experiment, was also increased by PHY pre-treatment of diet. Growth increment may attribute to phytate hydrolyzing capability of phytase (Cao et al., 2007). Similar to our results, improved growth performance by PHY pre-treatment of plant based diet was also observed for rainbow trout by Wang et al. (2009). Similarly, phytase supplementation has resulted in improved growth performance of various fish species including common carp (Sardar et al., 2007; Phromkunthong et al., 2010), gibel carp (Liu et al., 2011), catfish (Nwanna et al., 2005; Kim and Hung, 2007; Hung et al., 2014), tilpia (Cao et al., 2008; Tahoun et al., 2009) and rohu (Baruah et al., 2007a; Hussain et al., 2011).

In this study both supplements interacted positively $(p<0.05)$ to enhance growth performance of juveniles. Citric acid supplementation might have favored the activity of phytase by lowering the gut $\mathrm{pH}$ of juveniles in the range of its optimum activity. In contrast to our results, a non-significant interaction was observed by Zhu et al. (2014) between these two supplements for growth performance of yellow catfish. This discrepancy of results depends on varying fish species, physiological conditions of fish, culture conditions, processing methods and feed ingredients used for experimentation (Liebert and Portz, 2005).

In the present study, improved $(p<0.05)$ muscles and whole body dry mater was observed by feeding citric acid supplemented diet to rohu juveniles. Increased dry mater may attribute to the fact that citric acid efficiently hydrolyzed phytate and made chelated nutrients available (Koh et al., 2014). Similar to our results, increased dry matter contents in whole body of Seriola quinqueradiata was observed in response to citric acid supplementation as compared to control group (Sarker et al., 2012). Like dry matter elevated $(p<0.05)$ contents of crude protein in the juvenile's muscles as well as whole body were recorded by CA supplementation. Higher crude protein contents were may be due to two related factors: (i) the effect of dietary acidification and (ii) solubilization of protein-phytate complexes (Khajepour and Hosseini, 2012; Sarker et al., 2012a). However, in contrast to our results, Khajepour and Hosseini (2012) analyzed no significant differences in crude protein contents of common carp, Cyprinus carpio fed CA supplemented diets. Sarker et al. (2012) also observed that CA supplementation in different dietary groups showed no significant differences in whole body crude protein contents of yellowtail, Sariola quinqueradiata. A decrease in muscles and body crude fat contents were observed by dietary CA supplementation in the present study. In contrast to our results, Pagrus major which had $1 \%$ dietary CA supplementation showed no significant difference in crude fat contents compared to other supplementary organic acids and control group (Hossain et al., 2007). On the other hand, Pandey and Satoh (2008) observed significantly enhanced lipid contents in rainbow trout when fed on CA (1\%) supplemented fishmeal based diet. No or negative response to CA may likely be due to low level (1\%) of CA used in these studies as compare to present experiment as well as differences in feed formulation and culture species.

The dry matter contents of L. rohita juvenile were found significantly $(p<0.05)$ improved, in the present study, when fed phytase supplemented diet. This owe to the fact that PHY supplementation increased bioavailability of nutrients which intern reduced the moisture contents of tissues. Similar to our findings, Denstadli et al. (2007) also observed increased dry matter contents with PHY supplementation in Salmo salar. However, there was no significant improvement in dry matter contents with PHY supplementation in different studies on olive flounder (Paralichthys olivaceus) (Lee et al., 2008) and Nile tilapia (Liebert and Portz, 2005).

Phytate can directly react with charged groups of protein mediated by mineral cations, and thus adversely affect the bioavailability of protein (Urbano et al., 2000). In the present experiment, PHY supplementation had significantly $(p<0.05)$ improved the crude protein contents in the muscles and whole body of $L$. rohita juveniles. This might be due to the reduction of phytate-protein complexes by PHY action. Vielma et al. (2004) also reported positive effects of PHY supplementation on protein utilization in rainbow trout. Dephytinization of dietary phytate-protein complexes was also observed in Atlantic salmon (Sugiura et al., 1998) and common carp (Schafer et al., 1995) fed 
PHY supplemented diets. Again, L. rohita muscles and whole body crude fat contents, in the present study were decreased when fed on diet supplemented with PHY. Similar decreased in whole body crude fat in response to dietary PHY supplementation has been reported for grass carp (Liu et al., 2013) and Nile tilapia (Cao et al., 2008). Enhanced P concentration by PHY supplemented diets is probably the main cause of decreased crude fat of whole body, as, P causes B-oxidation of fatty acids. That's why the fish feeding on control diet (least $\mathrm{P}$ availability) showed maximum whole body crude fat contents (Schafer et al., 1995).

In the present study, a non-significant interaction was observed for muscles proximate composition of L. rohita. Both supplements (CA and PHY) interacted significantly to enhance the whole body dry matter and to lower the crude fat contents while interaction for crude protein was non-significant. Dietary microbial PHY and CA may act synergistically to enhance the availability of these nutrients by hydrolyzing the phytate moiety present in plant ingredients, and as a result improving the body composition of juveniles (Baruah et al., 2005, 2007a, b). Similarly, Baruah et al. (2007a) observed an interaction between CA and PHY to improve whole body proximate composition in L. rohita juveniles.

Citric acid, in the present study, had enhanced $(p<0.05)$ the minerals contents in the whole body of L. rohita juveniles. Dietary acidification might had reduced the $\mathrm{pH}$ of the experimental diet which led to gut acidification. The phytate-mineral complexes are likely to be solubilized at lower $\mathrm{pH}$, resulting in the release of bound cations. Subsequent chelation of these released cations by supplemented CA might had also played important role in improving the mineralization (Shah et al., 2015c). Similar findings were reported by Khajepour and Hosseini (2012) in beluga while feeding it with CA acidified diet. Improved whole body mineralization was recorded in response to dietary acidification in rainbow trout (Vielma et al. 1999).

Results from present study indicated elevated $(p<0.05)$ levels of $\mathrm{Mn}, \mathrm{Mg}, \mathrm{Na}, \mathrm{Ca}, \mathrm{Cu}, \mathrm{Fe}, \mathrm{P}$ and $\mathrm{Zn}$ in the whole body of $L$. rohita juveniles having PHY pretreated diet. During pre-treatment PHY might had hydrolyzed the phytate-mineral complexes present in plant ingredients hence released bound $\mathrm{P}$ as well as other chelated minerals leading to improved whole body mineralization. Laining et al. (2011) also found improved minerals deposition in juvenile tiger puffer, Takifugu rubripes in response to PHY supplementation. Improved whole body P, Ca and Mn contents were also reported in African catfish fed diet added with PHY (Nwanna et al., 2005). Similarly, in common carp, an agastric fish, PHY supplementation had resulted in increased whole body P concentration (Nwanna and Schwarz, 2007).

The present study showed synergism between supplements to improve mineral status of fish whole body. Acidification of diet with CA decreased the $\mathrm{pH}$ of gut and thus enhanced the effectiveness of microbial PHY (Baruah et al., 2007b) leading to enhanced minerals deposition. Baruah et al. (2005), in L. rohita juveniles, also found significant interaction between CA and PHY to improve whole body mineralization. From the present study, it can be concluded that pre-treatment of CA and PHY efficiently improved growth and nutrient status of $L$. rohita by acting individually as well as in combination.

\section{CONCLUSION}

The present study concluded that pre-treatment of sunflower meal with CA and PHY improved growth performance and chemical composition of muscles and whole body. Additionally, both supplements interacted significantly positively to improve growth, whole body proximate and some mineral parameters.

\section{Statement of conflict of interest}

The authors declare no conflict of interest.

\section{REFERENCES}

Afzal, M., Sultana, N., Hassan, A., Shah, S.Z.H., Fatima, M., Hussain, S.M., Bilal, M. and Hussain M., 2019. Effectiveness of acidification and phytase pretreatment on growth performance, muscle proximate composition and nutrient digestibility of Rohu (Labeo rohita, Hamilton 1822) juveniles fed soybean meal based diet. Pakistan J. Zool., 51: 1741-1750.

Akram, Z., Afzal, M., Shah, S.Z.H., Fatima, M., Akram, K., Hussain, S.M. and Shahzad, M.M., 2016. Role of citric acid and phytase supplementation in improving trace mineral retention in Rohu (Labeo rohita) juveniles fed soybean meal based diet. Biologia, 62: 87-93.

Allan, G.L. and Rowland, S.J., 1992. Development of an experimental diet for silver perch (Bidyanus bidyanus). Austasia Aquacult., 6: 39-40.

AOAC, 2000. Official methods of analysis of the Association of Official Analytical Chemists, $19^{\text {th }}$ edition. Association of Official Analytical Chemists, Arlington, VA.

Baruah, K., Pal, A.K., Sahu, N.P., Jai, K.K., Mukherjee, S.C. and Debnath, D., 2005. Dietary protein level, microbial phytase, citric acid and their interactions on bone mineralization of Labeo rohita (Hamilton) 
juveniles. Aquacult. Res., 36: 803-812. https://doi. org/10.1111/j.1365-2109.2005.01290.x

Baruah, K., Sahu, N.P., Pal, A.K., Jain, K.K., Debnath, D. and Mukherjee, S.C., 2007a. Dietary microbial phytase and citric acid synergistically enhances nutrient digestibility and growth performance of Labeo rohita (Hamilton) juveniles at sub-optimal protein level. Aquacult. Res., 38: 109-120. https:// doi.org/10.1111/j.1365-2109.2006.01624.x

Baruah, K., Pal, A.K., Sahu, N.P. and Debnath, D., 2007b. Interaction of dietary microbial phytase, citric acid and crude protein level on mineral utilization by rohu (Labeo rohita) juveniles. $J$. World Aquacult. Soc., 38: 129-137. https://doi. org/10.1111/j.1749-7345.2007.00092.x

Cao, L., Wang, W., Yang, C., Yang, Y., Diana, J., Yakupitiyage, A., Luo, Z. and Li, D., 2007. Application of microbial phytase in fish feed. Enzyme Microb. Technol., 14: 342-362.

Cao, L., Yang, Y., Wang, W., Yakupitiyage, A., Yuan, D.R. and Diana, J.S., 2008. Effects of pretreatment with microbial phytase on phosphorous utilization and growth performance of Nile tilapia (Oreochromis niloticus). Aquacult. Nutr., 14: 99-109. https://doi. org/10.1111/j.1365-2095.2007.00508.x

Carter, C.G. and Sajjadi, M., 2011. Low fishmeal diets for Atlantic salmon, Salmo salar L., using soy protein concentrate treated with graded levels of phytase. Aquacult. Int., 19: 431-444. https://doi. org/10.1007/s10499-010-9358-Z

Cheng, Z.J. and Hardy, R.W., 2002. Effects of microbial phytase on apparent nutrient utilization of barley, canola meal, wheat and wheat middlings, measured in vivo using rainbow trout (Oncorhynchus mykiss). Aquacult. Nutr., 8: 271-277. https://doi. org/10.1046/j.1365-2095.2002.00219.x

Cheng, Z.J. and Hardy, R.W., 2003. Effects of extrusion and expelling processing, and microbial phytase supplementation on apparent utilization coefficients of nutrients in full-fat soybeans for rainbow trout (Oncorhynchus mykiss). Aquaculture, 218: 501-514. https://doi.org/10.1016/S0044-8486(02)00458-1

Cosgrove, D.J., 1966. The chemistry and biochemistry of inositol polyphosphates. Rev. Pure appl. Chem., 16: $297-335$.

Craig, S.L. and Helfrich, A., 2002. Understanding fish nutrition, feeds and feeding. Department of Fisheries and Wild Life Sci. Virginia Tech., pp. 420-456.

Cross, H.S., Debiec, H. and Peterlik, M., 1990. Mechanism and regulation of intestinal phosphate absorption. Miner Electrol. Metab., 16: 115-124.
Dalasgaard, L.K., Ekmann, S., Pedersen, P.B. and Verlhac, V., 2009. Effect of supplemented fungal phytase on performance and phosphorus availability by phosphorus-depleted juvenile rainbow trout (Oncorhynchus mykiss), and on magnitude and composition of phosphorus waste output. Aquaculture, 286: 105-112. https://doi. org/10.1016/j.aquaculture.2008.09.007

Denstadli, V., Sttorebakken, T., Svihus, B. and Skrede, A., 2007. A comparison of online phytase pretreatment of vegetable feed ingredients and phytase coating in diets for Atlantic salmon (Salmo salar) reared in cold water. Aquaculture, 269: 414-426. https://doi. org/10.1016/j.aquaculture.2007.02.033

Eidelsburger, U., 1997. Organic acids and how they affect pig feeding. Optimization of feed quality is only one aspect. Schweinewelt, 22: 18-21.

Engelen, A.J., Van ver Heeft, F.C., Randsdrop, P.H.G. and Smith, E.L.C., 1994. Simple and rapid determination of phytase activity. J. AOAC Int., 77: 760-764.

Forster, I., Higgs, D.A., Dosanjh, B.S., Rowshandeli, M. and Parr, J., 1999. Potential for dietary phytase to improve the nutritive value of canola protein concentrate and decrease phosphorus output in rainbow trout (Oncorhynchus mykiss) held in $11^{\circ} \mathrm{C}$ fresh water. Aquaculture, 179: 109-125. https://doi. org/10.1016/S0044-8486(99)00156-8

Francis, G., Makkar, H.P. and Becker, K., 2001. Antinutritional factors present in plant derived alternate fish feed ingredients and their effects in fish. Aquaculture, 199: 197-227. https://doi.org/10.1016/ S0044-8486(01)00526-9

Hardy, R.W., 2000. New developments in aquatic feed ingredients and potential of enzyme supplements. In: Advances en Nutricion Acuicola V. Memorias del $V$ Simposium Internacional de Nutricion Acuicola (eds. L.E. Cruz-Suarez, D. Ricque-Marie, M. Tapia-Salazar, M.A. Olvera-Novoa and R. Civera-cerecedo). Merida, Yucatan, Mexico, pp. 216-226.

Hossain, M.A., Pandey, A. and Satoh, S., 2007. Effects of organic acids on growth and phosphorus utilization in red sea bream Pagrus major. Fish. Sci., 73: 1309-1317.

Hung, L.T., Thanh, N.T., Pham, M.A. and Browdy, C.L., 2014. A comparison of the effect of dietary fungal phytase and dicalcium phosphate supplementation on growth performance, feed and phosphorus utilization of tra catfish juveniles (Pangasianodon hypophthalmus Sauage, 1878). Aquacult. Nutr., 21: 10-17. https://doi.org/10.1111/anu.12134 
Hussain, S.M., Afzal, M., Rana, S.A., Javid, A. and Iqbal, M., 2011. Effect of phytase supplementation on growth performance and nutrient digestibility of Labeo rohita fingerlings fed on corn gluten mealbased diets. Int. J. Agric. Biol., 13: 916-922.

Khajepour, F. and Hosseini, S.A., 2012. Citric acid improves growth performance and phosphorus digestibility in Beluga (Huso huso) fed diets where soybean meal partly replaced fish meal. Anim. Feed Sci. Technol., 171: 6873. https://doi.org/10.1016/j. anifeedsci.2011.10.001

Kim, T.N.T. and Hung, L.T., 2007. Study of phytase effect on growth performance and feed utilization for basa catfish (Pangasius bocourti). Nong Lam J. Sci. Technol., 1\&2: 156-161.

Knuckles, B.E., Kuzmicky, D.D., Gumbmann, M.R.A. and Betschart, A., 1989. Effect of myo-inositol phosphate esters on in vitro and in vivo digestion of protein. J. Fd. Sci., 54: 1348-1350. https://doi. org/10.1111/j.1365-2621.1989.tb05989.x

Koh, C.B., Romano, N., Zahrah, A.S. and Ng, W.K., 2014. Effects of a dietary organic acids blend and oxytetracycline on the growth, nutrient utilization and total cultivable gut microbiota of the red hybrid tilapia, Oreochromis sp., and resistance to Streptococcus agalactiae. Aquacult. Res., 47: 357369. https://doi.org/10.1111/are.12492

Laining, A., Ishikwa, M., Kyaw, K., Gao, J., Binh, N.T., Koshio, S., Yamaguchi, S., Yokoyama, S. and Koyoma, J., 2011. Dietary calcium and phosphorus ratio influence the efficiency of microbial phytase on growth, mineral utilization and vertebral mineralization in juvinile tiger puffer, Takifugu rubripes. J. Aquacult. Nutr., 17: 267-277. https:// doi.org/10.1111/j.1365-2095.2009.00749.x

Lee, K.J., Pham, M.N., Dang, T.M., Lim, S.J., Ko, G.Y., Eo, J. and Oh, D.H., 2008. Improved apparent digestibility coefficient of protein and phosphorus by supplementation of microbial phytase in diets containing cottonseed and soybean meal for juvenile olive flounder (Paralichthys olivaceus). Asian-Aust. J. Anim. Sci., 21: 1367-1375. https:// doi.org/10.5713/ajas.2008.80053

Liebert, F. and Portz, L., 2005. Nutrient utilization of Nile tilapia Oreochromis niloticus fed plant based low phosphorus diets supplemented with graded levels of different sources of microbial phytase. Aquaculture, 248: 111-119. https://doi. org/10.1016/j.aquaculture.2005.04.009

Liu, B.L., Rafing, A., Tzeng, Y.M. and Rob, A., 2011. The introduction and characterization of phytase and beyond. Enzyme Microb. Technol., 22: 415-424.
https://doi.org/10.1016/S0141-0229(97)00210-X

Liu, L., Zhou, Y., Wu, J., Zhang, W., Abbas, K., Fang, L.X. and Luo, Y., 2013. Supplemental graded levels of neutral phytase using pretreatment and spraying methods in the diet of grass carp, Ctenopharyngodon idellus. Aquacult. Res., 45:1932-1941. https://doi. org/10.1111/are.12145

Makkar, H.P.S., 1993. Anti-nutritional factors in foods for livestock. In: Animal production in developing countries (eds. M. Gill, E. Owen, G.E. Pollot and T.L.J. Lawrence). Occasional Publication No. 16, Br. Soc. Anim. Prod., pp. 69-85. https://doi. org/10.1017/S0263967X00031086

Mushtaq, T., Sarwar, M., Ahmad, G.N. and Jamil, N.A., 2006. The influence of exogenous multi-enzyme preparation and graded levels of utilization sine on the performance of young broiler chicks two weeks post hatching in sunflower meal based diets. Poult. Sci., 85: 2180-2185. https://doi.org/10.1093/ ps/85.12.2180

Ng, W.K. and Koh, C.B., 2011. Application of organic acids in aquafeeds: impacts on fish growth, nutrient utilization and disease resistance. In: Standards for acidifiers, principles for the use of organic acids in animal nutrition (ed. C. Luckstadt). Nottingham University Press, Nottingham, UK, pp. 49-58.

Nwanna, L.C., Fagbenro, O.A. and Adeyo, A.O., 2005. Effects of different treatments of dietary soybean meal and phytase on the growth and mineral deposition in African catfish Clarias gariepinus. $J$. Anim. Vet. Adv., 4: 980-987.

Nwanna, L.C., Kolahsa, M., Eisenreich, R. and Schwarz, F.J., 2008. Pre-treatment of dietary plant feed stuffs with phytase and its effect on growth and mineral concentration in common carp (Cyprinus carpio). J. Anim. Physiol. Anim. Nutr., 92: 677-682. https:// doi.org/10.1111/j.1439-0396.2007.00764.x

Nwanna, L.C. and Schwarz, F.J., 2007. Effect of supplemental phytase on growth performance, phosphorus utilization and bone mineralization of common carp (Cyprinus carpio). Aquacult. Res., 38:1037-1044. https://doi.org/10.1111/j.13652109.2007.01752.x

Olusola, S.E. and Nwanna, L.C., 2014. Growth performance of Nile tilapia (Oreochromis niloticus) fed processed soybean meal based diets supplemented with phytase. Int. J. Aquacult., 4: 4854. https://doi.org/10.5376/ija.2014.04.0008

Pandey, A. and Satoh, S., 2008. Effect of organic acid on growth and phosphorous utilization in rainbow trout Oncorhynchus mykiss. J. Fish. Sci., 74: 867-874. https://doi.org/10.1111/j.1444-2906.2008.01601.x 
Pham, M.A., Lee, K.J., Dang, T.M., Lim, S.J., Eo, G.J. and Oh, D.H., 2008. Improved apparent utilization coefficient of protein and phosphorus by supplementation of microbial phytase in diets containing cottonseed and soybean meal for juvenile olive flounder (Paralichthys olivaceus). Asian-Austral. J. Anim. Sci., 21: 1367-1375. https:// doi.org/10.5713/ajas.2008.80053

Phromkunthong, W., Nuntapong, N. and Gabaudan, J., 2010. Interaction of phytase RONOZYME®P (L) and citric acid on the utilization of phosphorus by common carp (Cyprinous carpio). Songklanakarin J. Sci. Technol., 32: 547-554.

Ravindran, V. and Kornegay, E.T., 1993. Acidification of weaner pig diets: A review. J. Sci. Fd. Agric., 62: 313-322. https://doi.org/10.1002/jsfa.2740620402

Robinson E.H., Li, M.H. and Manning, B.B., 2002. Comparison of microbial phytase and dicalcium phosphate for growth and bone mineralization of pond-raised channel cat fish (Ictalurus punctatus). J. appl. Aqacult., 12: 81-88. https://doi.org/10.1300/ J028v12n03_08

Rowland, S.J. and Ingram, B.A., 1991. Diseases of Australian native fishes. Fisheries Bulletin 4 NSW Fisheries, Sydney, NSW, Australia.

Sajjadi, M. and Carter, C.G., 2004. Dietary phytase supplementation and the utilization of phosphorus by Atlantic salmon, Salmo salar fed a canola-mealbased diet. Aquaculture, 240: 417-431. https://doi. org/10.1016/j.aquaculture.2004.07.003

Sardar, P., Randhawa, H.S., Abid, M. and Prabhakar, S.K., 2007. Effect of dietary microbial phytase supplementation on growth performance, nutrient utilization, body compositions and haematobiochemical profiles of Cyprinus carpio (L.) fingerlings fed soyprotein-based diet. Aquacult. Nutr., 13: 444-456. https://doi.org/10.1111/j.13652095.2007.00497.x

Sarker, S.A., Satoh, S. and Kiron, V., 2007. Inclusion of citric acid and/or amino acid-chelated trace elements in alternate plant protein source diets affects growth and excretion of nitrogen and phosphorus in red sea bream Pagrus major. Aquaculture, 262: 436-443. https://doi.org/10.1016/j.aquaculture.2006.10.007

Sarker, M.S.A., Satoh, S., Kamata, K., Haga, Y. and Yamamoto, Y., 2012. Partial replacement of fish meal with plant protein sources using organic acid to practical diet for juveniles yellowtail, Sariola quinqueradiata. Aquacult. Nutr., 18: 81-89. https:// doi.org/10.1111/j.1365-2095.2011.00880.x

Schafer, A., Koppe, W.M., Meyer-Burgdorff, K.H. and Gunther, K.D., 1995. Effect of a microbial phytase on utilization of native phosphorus by carp in a diet based on soybean meal. Water Sci. Technol., 31: 149-155. https://doi.org/10.2166/wst.1995.0372

Shah, S.Z.H., Afzal, M., Fatima, M., Hussain, S.M., Bhatti, M.A. and Hayat, H.F., 2015 a. Supplementation of phytase and citric acid to soybean meal based diet enhance muscle mineralization of rohu, Labeo rohita, juveniles. $J$. Sci., 5: 796-800.

Shah, S.Z.H., Afzal, M., Hussain, S.M., Fatima, M., Bilal, M., Ahmed, T. and Habib, R.Z., 2015 b. Supplementation of citric acid and phytase improves the digestive enzymes activities in Labeo rohita fingerlings. Biologia, 61: 63-68.

Shah, S.Z.H., Afzal, M., Khan, S.Y., Hussain, S.M. and Habib, R.Z., 2015c. Prospects of using citric acid as fish feed supplement. Int. J. Agric. Biol., 17: 1-8.

Shah, S.Z.H., Afzal, M., Akmal, A., Fatima, M. and Hussain, S.M., 2016. Effect of citric acid and phytase on growth performance and mineralization of Labeo rohita juveniles fed soybean meal based diet. Int. J. Agric. Biol., 18: 111-116. https://doi. org/10.17957/IJAB/15.0071

Shaheen, T., Ayub, M., Hayat, S., Abidi, S.Z.A. and Tahir, S., 2000. Impact of different levels on the survival and growth of Labeo rohita at constant level of protein. Pak. J. Fish., 1: 95-102.

Snedecor, G.W. and Cochran, W.G., 1991. Statistical methods, $8^{\text {th }}$ ed. Iowa State University Press, Ames, USA, pp. 503.

Storebakken, T., Refstie, S. and Ruyter, B., 2000. Soy products as fat and protein sources in fish feeds for intensive aquaculture. In: Soy in animal nutrition (ed. J.K. Drackley). Fed Anim. Sci. Soc., Savoy, IL, USA, pp. 127-170.

Sugiura, S.H., Dong, F.M. and Hardy, R.W., 1998. Effects of dietary supplements on the availability of minerals in fish meal; preliminary observations. Aquaculture, 160: 283-303. https://doi.org/10.1016/ S0044-8486(97)00302-5

Sugiura, S.H., Gabaudan, J., Dong, F.M. and Hardy, R.W., 2001. Dietary microbial phytase supplementation and the utilization of phosphorus, trace minerals and protein by rainbow trout Oncorhynchus mykiss (Walbaum) fed soybean meal-based diets. Aquacult. Res., 32: 583-592. https://doi.org/10.1046/j.13652109.2001.00581.x

Tahoun, A.M., Abo-State, H.A. and Hammouda, Y.A., 2009. Effect of adding commercial phytase to DDGS based diets on the performance and feed utilization of Nile tilapia (Oreochromis niloticus) fingerlings. American-Eurasian J. Agric. environ. 
Sci., 5: 550-555.

Urbano, G., Lopez-Jurado, M., Aranda, C., Vidal, V., Tenorio, E. and Porres, J., 2000. The role of phytic acid in legumes: Antinutrient or beneficial function. J. Physiol. Biochem., 56: 283-294. https://doi. org/10.1007/BF03179796

Usmani, N. and Jafri, A.K., 2002. Influence of dietary phytic acid on the growth, conversion efficiency, and carcass composition of mrigal, Cirrhinus mrigala fry. J. World Aquacult. Soc., 33: 199204. https://doi.org/10.1111/j.1749-7345.2002. tb00495.x

Vielma, J., Ruohonen, K. and Lall, S.P., 1999. Supplemental citric acid and particle size of fish bone-meal influence the availability of minerals in rainbow trout Oncorhynchus mykiss (Walbaum). $J$. Aquacult. Nutr., 5: 65-71. https://doi.org/10.1046/ j.1365-2095.1999.00092.x

Vielma, J., Ruohonen, K. and Peisker, M., 2002. Dephytinization of two soy proteins increases phosphorus and protein utilization by rainbow trout, Oncorhynchus mykiss. Aquaculture, 204: 145-156. https://doi.org/10.1016/S0044-8486(01)00653-6

Vielma, J., Ruohonen, K., Gabaudan, J. and Vogel, K., 2004. Top spraying soybean meal-based diets with phytase improves protein and mineral digestibilities but not lysine utilization in rainbow trout, Oncorhynchus mykiss (Walbaum). Aquacult. Res., 35: 955-964. https://doi.org/10.1111/j.13652109.2004.01106.x
Wang, F., Yang, Y., Han, Z., Dong, H., Yang, C.H. and Zou, Z., 2009. Effects of phytase pretreatment of soybean meal and phytase-sprayed in diets on growth, apparent utilization coefficient and nutrient excretion of rainbow trout (Oncorhynchus mykiss Walbaum). J. Aquacult. Int., 17: 143-157. https:// doi.org/10.1007/s10499-008-9187-5

Yoo, G.Y., Wang, X., Choi, S., Han, K., Kang, J.C. and Bai, S.C., 2005. Dietary microbial phytase increased the phosphorus utilization in juvenile Korean rockfish Sebastes schlegeli fed diets containing soybean meal. Aquaculture, 243: 315-322. https:// doi.org/10.1016/j.aquaculture.2004.10.025

Zhou, Q., Tan, B.P., Mai, K.S. and Liu, Y.J., 2004. Apparent utilization of selected feed for juvenile cobia Rachycentron canadum. Aquaculture, 241: 441-445. https://doi.org/10.1016/j. aquaculture.2004.08.044

Zhu, Y., Qiu, X., Ding, Q., Duan, M. and Wang, C., 2014. Combined effects of dietary phytase and organic acid on growth and phosphorus utilization of juvenile yellow catfish Pelteobagrus fulvidraco. Aquaculture, 430: 1-8. https://doi.org/10.1016/j. aquaculture.2014.03.023

Zyla, K., Ledoux, D.R., Garcia, A. and Veum, T.L., 1995. An in vitro procedure for studying enzymic dephosphorylation of phytate in maize-soybean feeds for turkey poults. Braz. J. Nutr., 74: 3-17. https://doi.org/10.1079/BJN19950102 